\title{
The Tlonic World of Harry Potter: An Idealistic Version of Magical World
}

\author{
Bahee Hadaegh (Correspondent Author) \\ Dept. of Foreign Languages, Faculty of Literature and Humanities, Shiraz University, Shiraz, Iran. \\ E-mail: bhadaegh@rose.shirazu.ac.ir \\ Parvaneh Javidnejat \\ Dept. of Foreign Languages, Faculty of Literature and Humanities, Shiraz University, Iran
}

Received: 10-07-2015

Published: 01-01-2016
Accepted: 23-10-2015

doi:10.7575/aiac.ijalel.v.5n.1p.224
Advance Access Published: October 2015

URL: http://dx.doi.org/10.7575/aiac.ijalel.v.5n.1p.224

\begin{abstract}
Considered as literary pieces of fantasy and secondarily a possible version of magic realism, J.K. Rowling's seven Harry Potter (1997-2007) novels have been involving the readers of different age groups and succeeded in unleashing the target imagination. Taking into account the different probable associations, it is of novelty to draw comparisons between the magical world of Harry Potter (1997-2007) and that of Tlon in Jorge Luis Borges' short story "Tlon, Uqbar, Orbis, Tertius" (1941). In both worlds there exist images and implied notions that serve to naturalize the supernatural and to blur the line between the real and the imaginary. Making use of Berkeleyan theory of idealism, the power of mind is emphasized upon due to its capability of bringing into existence any object, concept or incident that seems materially and logically impossible. Meanwhile, an abstract force that is Love is highlighted in the novels that could be assumed as functioning like the omniscient God of Berkeley holding the universe together with its mere presence. Therefore, a new perspective in discovering a truth of life would be dragged into view as a result of the products of one's mind.
\end{abstract}

Keywords: Harry Potter, J.K. Rowling, “Tlon, Uqbar, Orbis, Tertius", Jorge Luis Borges, George Berkeley, Idealism

\section{Introduction}

J.K. Rowling's seven Harry Potter novels (1997-2007) have been received worldwide in the twenty first century whose majority of the inhabitants is being targeted with day-by-day advances of technology and pushing deep down into a common kind of materialism. It is therefore of tremendous relief to announce that the mentioned series of novels have hit the market as blockbusters or even monetary phenomena, as some critics claim, and successfully pulled out many children and adults from the described descent of automation. The proof to the claim, according to Operah Winfrey (2013), is manifest in the novels' translation into more than sixty nine languages in approximately two hundred countries worldwide under the titles: Harry Potter and the Philosopher's Stone (1997) referred to in this study as HPS, Harry Potter and the Chamber of Secrets (1998, HCS), Harry Potter and the Prisoner of Azkaban (1999, HPA), Harry Potter and the Goblet of Fire (2000, HGF), Harry Potter and the Order of the Phoenix (2003, HOP), Harry Potter and the Half-Blood Prince (2005, HHP), and finally Harry Potter and the Deathly Hallows (2007, HDH).

The novels as objects of cultural phenomena are presumed to be more than merely representatives of the children's literature of escape and commercialism. In order to meet such expectation, papers and books have been written touching upon different aspects which lead to a better exploration of the series' depth and a profound understanding of the themes. Among the most significant contributions, the followings can be mentioned: Biswas's exploration of magic realism in the series, Cherland's detection of discourse of gender, Natov's searching for the ordinariness in the extraordinary nature of the novels, Krueger-Kischak's discovering the allusions to God and the concept of love, Stojilkov's theory of the immortality of love in Harry Potter (1997-2007), and many different other perspectives that have been taken into account regarding the series. The significance of this research study is to hopingly contain a new approach different from the ones made so far which contributes to the weight of the existing researches on the Harry Potter (1997-2007) series through juxtaposing the magical world of Harry with the idealistic one of Jorge Luis Borges's Tlon which has not been dealt with previously and can be considered as original in choosing idealism for its methodology.

Whether or not Rowling had been bearing particular objectives in mind while writing the pages rather than assumingly striking it rich, it is of importance to elaborate on some of the novels' themes and possible associations; Furthermore, the excavation of the metaphysical perspectives can lead to a contemporary re-presenation and elucidation of what traditional philosophy and literature have stored in repertoire. 


\section{Beyond Fantastical Fiction}

One can consider the fantasy novels of Harry Potter (1997-2007) as magic realism as well, taking into consideration the combination of a realistic, however simple narrative and surreal elements of fantasy used in the series:

Magic realism is a fictional technique that combines fantasy with raw physical reality or social reality in a search for truth beyond that available from the surface of everyday life. The startling irony behind this is that only through the conjunction of the fantastic and the factual can truth fully emerge in literature (Mellen, 2000, p.1).

Applying the mentioned features to Rowling's case, Harry Potter (1997-2007) while being a fantastical writing piece rife with mysterious and adventurous events embedded in the plot can be regarded as an attempt of the author probing into the mysteries of life and human interpersonal and intrapersonal relationships which most importantly convey social implications at the same time, particularly in children's society. As for the metaphysical part of the story, one cannot deny the significance and power of love as a driving force for its being the ultimate truth within and without the context in all the seven works. Critic Leal (2005) in his essay focuses on such sort of seeing beyond:

In magical realism key events have no logical or psychological explanation. The magical realist does not try to copy the surrounding reality (as the realists did) or to wound it (as the surrealists did) but to seize the mystery that breathes behind things (p.123).

Enhancing the realistic load of the series in line with the mysteries of life, namely love, Gupta (2003) maintains that the text-to-world reading of the series evokes three different worlds; that of the magic world which cannot be perceived by the non-magical people and is resided by Harry and his fellow wizards and witches all through school year, the Muggle world in which non-magical human beings such as Harry's aunt and her family reside, and our world as the readers (pp. 86-91). This is the particular connection between and fusion of realism and magic to be relied upon in application of idealism to the series:

In Rowling's stories, the interpenetration of the two worlds suggests the way in which we live, not only in childhood, though especially so _ on more than one plane, with the life of the imagination and daily life moving in and out of our consciousness. The two realms, characterized in literature as the genres of romance and realism, are located in the imagination, which is, always, created by and rooted in the details of everyday life. (Natov, 2001, p. 314)

Consequently, and in spite of all the existing critics' condemnation of the books for their being a quilt of imitation from classic children's stories, the achieved success due to its activating the minds of the readers in trying to find the relations to whatever humanistic notions is of noteworthiness.

\section{Theoretical Framework}

None of the existing studies on the Harry Potter (1997-2007) novels has inspected the associated Borgesian-like images and Berkeleyan idealism. As a result of such framework, the border between the assumed factual reality and the dreamlike nature of our lives reflected in Tlon and Harry Potter's world would be erased for the audience of the twenty first century as Berkeley or Borges prophetically essayed in doing so through introducing the capacity of our minds to imagine and create. Lingering along an understanding that this world can be the product of our mind, it would not be far-fetched to analyze these two imaginary worlds of Rowling and Borges on one basis.

In the epic plot of the cliché battle of the good and evil, there exist Harry potter the teenaged boy as the epitome of innocence and morality who outdid the fatal curse of Avada Kedavra and on the opposite side, Lord Voldemort, the relentless, devilish enemy of Harry's and the magical world in general who goes out of his way to outdo Death but in vain. As might be expected of such duality, many magical duels, incantations, and supernatural incidents would constitute the plot. Broadening the magicality of the works and of course underneath the surface, lies the philosophical conception of the faculty of mind and its power to bring into existence whatever seemingly awkward and fantastical in the world of Harry Potter (1997-2007). The microcosm could resemble a phantasmagoria; one that could be a contemporary representation of the famous universe that was earlier portrayed in the works of the Argentine author and poet, Jorge Luis Borges. Borges is highly popular for having created numerous intellectual works of literature in which the narrative and the surreal imagery are intertwined in order to depict an entirely different world of magic. Such a world is named Tlon in one of his short stories, “Tlon, Uqbar, Orbis, Tertius" (1941). Like Harry's world, this one reveals supernaturalism and mysterious circumstances, and this paper aims to exhibit the probable existing similarities between the magical worlds of Borges and Rowling, bearing as its backdrop theory the Berkelyan philosophy.

\subsection{The Problem of the External World}

Modern Philosophy has witnessed different shades of opposing and conforming theories. As a reaction against the Descartian philosophy in general and at the same time keeping the proposition of certainty of one's own act of thinking, empiricism was reborn in a similar fashion as Francis Bacon's through the contributions of philosophers such as Locke, Berkeley, and Hume. Bishop Berkeley of the seventeenth century Ireland differed from the other two thinkers in the fact that he allotted some room for the existence of God and spirits or what is known to be metaphysics. "A Treatise Concerning the Principles of Human Knowledge" (1710) frames his theories and is referred to as the backbone of this paper. Berkeley's name has been interlaced with immaterialism, a concept holding that the material world does not exist. He does not mean to deny the existence of books, televisions, or any other material objects; what he is rejecting is that their existence implies the existence of material substance which cannot all the time be perceived by us. Thereupon, 
he asserts that in the existence of a perceived external physical object, the sensation of particular sensible qualities is at work. These qualities do not exist when we are not perceiving them, like when the time we are outside the room with the mentioned book or TV in it; As a result, the physical object does not exist either.

In addition to the notion of immaterialism, the main leverage as to the propelling of this research arises in the discussion of idealism. The chief point in empirical philosophy is that all our ideas come to us from experience which would engage our senses and also our reflection faculty. The word "idea" in this aspect bears significance in the fact that it is the object of thought and experience. The existence of ideas thoroughly depends on the existence of the particular sensation or thought of which it is the object. Berkeley elaborates on the nature of human perception and holds that the outside world is made of ideas which are classified into three realms of sensation, thought, and imagination. Hence, an idea exists only and only if perceived by the mind which is the main principle of human knowledge; "Esse est percipi":

. . . besides all that endless variety of ideas or objects of knowledge, there is likewise something which knows or perceives them, and exercises divers operations, as willing, imagining, remembering about them. This perceiving, active being is what I call mind, spirit, soul or myself. By which words I do not denote any one of my ideas, but a thing entirely distinct from them, wherein they exist, or, which is the same thing, whereby they are perceived; for the existence of an idea consists in being perceived (Berkeley, 1710, pp. 65-66).

Berkeley reinforces the idea and pinpoints that when humans do their utmost to conceive the existence of external bodies, they are all the while only contemplating their own ideas. But, the mind taking no notice of itself, is deluded to think it can and doth conceive bodies existing unthought-of or without the mind (1710, p.76).

\subsection{The Borgesian Trend}

Facilitating a better understanding of Berkeley's philosophy in this regard, the applied theories in Jorge Louis Borges' literary works can be introduced. In an interview, titled "Merely a Man of Letters" (1977), this Argentine author highlights the philosophy behind his imaginary world as this:

Then I came to the idea of how fine it would be to think of . . . an imaginary world, where everything should be linked. Where, for example, you would have, let's say, a language and then a literature that went with the language, and then a history with it, and so on. . . . Then, as I needed a quite different world from ours - it wasn't enough to invent fancy names - I said, why not a world based on, let's say, Berkeleyan ideas? . . . Then I wrote that story, "Tlön, Uqbar, Orbis Tertius" that day, which has attracted many readers. And of course, the whole thing was based on the theory of idealism, the idea of there being no things but only happenings, of there being no nouns but only verbs, of there being no things but only perceptions . . . I suppose that my thinking has been done for me by Berkeley, by Hume, by Schopenhauer, by Mauthner perhaps. (Borges, pp. 339-40)

The relation between Borges and the aforementioned philosophers is a truth universally acknowledged:

There is no doubt that Borges accepts and modifies Berkeley's doctrine. He likes quoting sections 3 and 6 of the Principles and seems to agree wholeheartedly with every word, every expression that he patiently translates into clear and elegant Spanish. He does so in 1925 when he writes "La encrucijada de Berkeley," included in his first collection of essays, Inquisiciones; and later, in 1944 and 1946 when he publishes the two essays that compose "Nueva refutación del tiempo." [a New Refutation of Time]. (Martin, 2000, p.157)

Despite some differences in the beliefs held by these two thinkers, Berkeley and Borges both believe in the minddependency of our world. On this subject, Borges' short story is abundant in instances where physical objects are brought into existence by the force of imagination and ideas which have the ability to affect the reality. "Ironically, Tlön commences to displace the known world; Tlön itself becomes an hrönir - a terrible new reality produced by wishfulfillment!" (Clark, 1995, p.78). Hronirs, as explained in the short story, are objects brought into existence by merely hoping so; and if Tlon is considered one in Clark's opinion, the same can be said regarding the magical world of Harry Potter (1997-2007) satisfying the immaterial needs of the contemporary readers, J.K. Rowling has provided us with an intelligible case. Whether or not she had been aware of the parallelism with Borges' creations, the universe of Harry Potter (1997-2007) was construed in such a way as to open up the portals of imagination for readers specially the young ones and their elder reading partners as well as reflecting the power of mind.

\section{Discussion}

Pertaining to the Borgesian universe, some images and themes must be brought forth to the limelight of the many are: the issue of time, the apparition of the material objects out of non-existence, and elements such as mirrors and labyrinths. Although the Borgesian canon is replete with all these elements, "Tlon, Uqbar, Orbis, Tertius" (1941) has been chosen because of its introducing a completely new universe that evokes Harry Potter's (1997-2007) magical universe:

"Tlon" is also the story in which Borges exhibits most forcefully the contention that reality cannot be distinguished from fiction. Finally, in "Tlon" Borges employs to the utmost one of his favorite literary devices for erasing the line between the fictitious and the real, the juxtaposition of real and fictitious characters and events. (Bossart, 2003, p.32) 
4.1 Tlonic World

Borges the narrator and his friends were sitting at their villa determined to find some information on the unregistered country called Uqbar; however, in vain:

I surmised that that undocumented country and its anonymous heresiarch were a fiction that Bioy had invented on the spur of the moment, out of modesty, in order to justify a fine-sounding epigram. A sterile search through one of the atlases of Justus Perthes reinforced my doubt. (Borges, p.38)

As the story goes on, the probability of the existence of such a world gets higher and higher, until it reaches a point where the reader takes the minute descriptions of Tlon to be highly persuasive proofs as for its existence, with actual references to the theories of philosophers like George Berkeley in the story and of course geographical regions.

Idealism as the foundation of the existence of Tlonic universe is sketched in the lines of the story introducing a kind of association of ideas within the mind:

Hume remarked once and for all that the arguments of Berkeley were not only thoroughly unanswerable but thoroughly unconvincing. This dictum is emphatically true as it applies to our world; but it falls down completely in Tlon. The nations of that planet are congenitally idealist ... extreme idealism, completely invalidates science. To explain or to judge an event is to identify or unite it with another one. In Tlon, such connection is a later stage in the mind of the observer, which can in no way affect or illuminate the earlier stage . . . From all this, it would be possible to deduce that there is no science in Tlon, let alone rational thought. (Borges, pp.80-81)

In the stream of associations within the mind, time and temporality would definitely lose their denotation and integrity. A chaotic sense of the past, present, and future rules over the Tlonic universe of Borges in which, relying on the power of mind and imagination, "the world is not a concurrence of objects in space, but a heterogeneous series of independent acts. It is serial and temporal, but not spatial” (Borges, p.80).

Ideal objects abound, invoked and dissolved momentarily, according to poetic necessity. . . I have remarked that the men of that planet conceive of the universe as a series of mental processes whose unfolding is to be understood only as a time sequence. (Borges, pp. 80-81)

According to Barrenechea (1965):

The insinuation of the precariousness of human existence, founded on the substance of time, contributes poetry and emotion to Borges' pages. But time has another significant function in his work it constitutes one of those concepts which must be disintegrated in order to destroy the individual's awareness of himself as a real and self-contained entity. . . The modification of the past can be another instance where as an example in Tlon, man-imagined elements are introduced into the second fictitious plane of Tlon, where the production of objects is accomplished by a thought process. (pp. 103-110)

As said earlier, Borges was constantly obsessed with demonstrating intellectual depth in his works of magic realism and he narrates:

The metaphysicians of Tlon are not looking for truth, nor even for an approximation of it; they are after a kind of amazement. They consider metaphysics a branch of fantastic literature. They know that a system is nothing more than the subordination of all the aspects of the universe to some one of them. (Borges, p.81)

This amazement would definitely lead to the discussion of the source behind all the creation:

This felicitous supposition declared that there is only one Individual, and that this indivisible Individual is every one of the separate beings in the universe, and that those beings are the instruments and masks of divinity itself . . . it permitted the cult of the gods to be retained. (Borges, p.82)

And reaching an ordered chaos, he concludes as the following:

. . . useless to reply that reality, too, is ordered. It may be so, but in accordance with divine laws - I translate: inhuman laws - which we will never completely perceive. Tlon may be a labyrinth, but it is a labyrinth plotted by men, a labyrinth destined to be deciphered by men. (Borges, p.86)

\subsection{The Parallel World of Harry Potter}

Clippings from the Harry Potter series must be put forth in order to draw the parallelism with the Tlonic world. The issue of imagination versus reality must be kept in view. In the very beginning of the series, the consciousness of the fact that two different worlds of magic and non-magic are being dealt with, is ingrained in the readers' minds. In a far less intricate diction but in the same situation as Borges' short story, people who do and those who do not approve of imagination and the power of mind to create things exist. That is in itself an invitation for the readers to follow the series via portals of imagination:

He [Uncle Vernon] also thought he had been called a Muggle [non-magical people], whatever that was. He was rattled. He hurried to his car and set off home, hoping he was imagining things, which he had never hoped before, because he didn't approve of imagination. (Rowling, HPS, p.10) 
Having been introduced to the magical world of Harry and the Hogwartz School as its headquarters, one might get interested in the way Rowling has provided the whereabouts of this magical area. Just like Tlon, Hogwarts is not documented officially either. Furthermore, the school is only one of the magical schools which exist worldwide. In his fourth year when he was involuntarily chosen as a participant of the Triwizard Tournament, Hermione Granger informs Harry so:

According to An Appraisal of Magical Education in Europe, it [another school of witchcraft and wizardry called Durmstrang] puts a lot of emphasis on the Dark Arts." "I think I've heard of it," said Ron vaguely. "Where is it? What country?" "Well, nobody knows, do they?" said Hermione, raising her eyebrows. "Er - why not?” said Harry. "There's traditionally been a lot of rivalry between all the magic schools. Durmstrang and Beauxbatons like to conceal their whereabouts so nobody can steal their secrets," said Hermione matter-of-factly . . . "But Hogwarts is hidden," said Hermione, in surprise. . . "It's bewitched," said Hermione. "If a Muggle looks at it, all they see is a moldering old ruin with a sign over the entrance saying danger, do not enter, unsafe." . . . And to keep foreign wizards from finding it, they'll have made it Unplottable — "Come again?" "Well, you can enchant a building so it's impossible to plot on a map, can't you?”. (Rowling, HGF, pp. 147-148)

Tlonic, regarding the absence of science and logic in the magical world of Harry, so much depends on the metaphysics of imagination and the mind of the magical people. The processes are highly organized in mind and the outcome relies on the determination through which a necessity is being called into mind. Immaterial existence as the ground of all the magical incidents would be assigned as the philosophical core of the Harry Potter series. The issue of existence and what it means or means not to exist is depicted in the last novel which in itself proves that the reader probably needs to think more deeply as the story would nearly end:

How can I possibly prove it [a magical stone] doesn't exist? Do you expect me to get hold of — of all the pebbles in the world and test them? I mean, you could claim that anything's real if the only basis for believing in it is that nobody's proved it doesn't exist! (Rowling, $H D H$, p.334)

The concrete examples of bringing things and images into existence are the Room of Requirement, the Patronus Charm, the Grimauld Palace, and the visions reflected from specific mirrors. In the case of the Room of Requirement, a need and perception was evoked in Harry's mind:

We need somewhere to learn to fight. . . . he thought. Just give us a place to practice . . . somewhere they can't find us . . . A highly polished door had appeared in the wall. Ron was staring at it, looking slightly wary. Harry reached out, seized the brass handle, pulled open the door, and led the way into a spacious room lit with flickering torches like those that illuminated the dungeons eight floors below. The walls were lined with wooden bookcases, and instead of chairs there were large silk cushions on the floor. (Rowling, HOP, p.345)

The same principle endures in Tlon where via exercising hope, objects come into existence, “. . the ur, which is a thing produced by suggestion, an object brought into being by hope" (Borges, 84). Hope in Harry Potter is replaced by need in the case of the Room of Requirements and keeps its positive force of happiness in the case of the Patronus Charm. In conjuring the shield charm, Harry needed to protect himself from the harm of the Dementors, the entities who guarded the prison of Azkaban and sucked the happiness out of their victims' souls by giving them the Dementor's Kiss. While being asked how the charm would operate and be created, Harry's professor replied:

"The Patronus is a kind of positive force, a projection of the very things that the Dementor feeds upon - hope, happiness, the desire to survive - but it cannot feel despair, as real humans can, so the Dementors can't hurt it ... With an incantation, which will work only if you are concentrating, with all your might, on a single, very happy memory." (Rowling, $H P A$, p.176)

In another occasion in the fifth book when Lupin, Harry's professor of the Defense Against the Dark Arts, took him to the station for the Order of the Phoenix, we have this happening that is highly associated with the operations in one's mind:

"Think about what you've just memorized," said Lupin quietly. Harry thought, and no sooner had he reached the part about number twelve, Grimmauld Place, than a battered door emerged out of nowhere between numbers eleven and thirteen, followed swiftly by dirty walls and grimy windows. It was as though an extra house had inflated, pushing those on either side out of its way. Harry gaped at it. The stereo in number eleven thudded on. Apparently the Muggles inside hadn't even felt anything. (Rowling, HOP, p.58)

Mirrors are inevitable part of a magical world functioning in a unique, fantastical way in Harry Potter. To begin with, there is the mirror of Erised which when Harry had the chance to look at, would reflect back his family despite their being dead. The reason was fundamentally implanted in his inner desire and willing to perceive and it left Harry in front of the mirror numb with a mixture of joy and sadness:

It was a magnificent mirror, as high as the ceiling . . . he had seen not only himself in the mirror, but a whole crowd of people standing right behind him. But the room was empty. . . . Harry looked over his shoulder - but, still, no one was there. Or were they all invisible, too? Was he in fact in a room full of invisible people and this mirror's trick was that it reflected them, invisible or not? He looked in the 
mirror again. A woman standing right behind his reflection was smiling at him and waving. $\mathrm{He}$ reached out a hand and felt the air behind him. If she was really there, he'd touch her, their reflections were so close together, but he felt only air — she and the others existed only in the mirror. (Rowling, HPS, pp. 152-3)

The headmaster of the school, Dumbledore, finally informed Harry about the secret behind the mirror:

It shows us nothing more or less than the deepest, most desperate desire of our hearts . . . However, this mirror will give us neither knowledge nor truth. Men have wasted away before it, entranced by what they have seen, or been driven mad, not knowing if what it shows is real or even possible . . It does not do to dwell on dreams and forget to live, remember that. (Rowling, HPS, p.157)

In another instance, we have the mirror which Sirius, Harry's godfather, had sent him as a Christmas present. Attached to it was a note:

This is a two-way mirror. I've got the other. If you need to speak to me, just say my name into it; you'll appear in my mirror and I'll be able to talk in yours. James [Harry's father] and I used to use them when we were in separate detentions. And Harry's heart began to race. He remembered seeing his dead parents in the Mirror of Erised four years ago. (Rowling, HOP, pp.755-56)

The issue of time in terms of its reversibility is another similar topic to Borgesian notion of time. Hermione, Harry, and Ron once traveled back in time and even changed the earlier incidents. The first instance of meddling with time and the power to dismantle it is shown in the third book when Hermione is secretly using the Time Turner given to her by professor Dumbledore:

"But look," said Ron, laughing, "see this morning? Nine o'clock, Divination. And underneath, nine o'clock, Muggle Studies. And" — Ron leaned closer to the schedule, disbelieving — "look underneath that, Arithmancy, nine o'clock. I mean, I know you're good, Hermione, but no one's that good. How're you supposed to be in three classes at once?" (Rowling, HPA, p.76)

"Harry looked around too. Hermione hadn't entered the classroom, yet Harry knew she had been right next to him when he had opened the door" (Rowling, HPA, p.217). Regarding the possibility of modifying the past, when Sirius Black, who had long been imprisoned in Azkaban was once again in the danger of being recaptured, Harry, Ron, and Hermione needed to have more time:

Hermione turned the hourglass over three times. The dark ward dissolved. Harry had the sensation that he was flying very fast, backward . . "What - how - Hermione, what happened?" "We've gone back in time," Hermione whispered . . "Shh! Listen! Someone's coming! I think — I think it might be us! . . "Are you telling me," Harry whispered, "that we're here in this cupboard and we're out there too?" "Yes," said Hermione, her ear still glued to the cupboard door. "I'm sure it's us. It doesn't sound like more than three people . . . and we're walking slowly because we're under the Invisibility Cloak." (Rowling, $H P A$, pp. 288-9)

Traveling back in time and entering the realm of memories, in his second school year, Harry is tricked into communicating with someone from the past through a diary. The writing pal who introduced himself to Harry as Tom Riddle once wrote: "I can take you inside my memory of the night when I caught him [the person who had opened the chamber of Secrets in Hogwartz the previous time]" (Rowling, HCS, p.180). "[Tom is] "A memory", said Riddle quietly. "Preserved in a diary for fifty year."” (Rowling, HCS, p.227). In the sixth year, Dumbledore and Harry take long walks wandering through the memories which Dumbledore had retrieved in the Pensieve. And things are re-seen in exactly the same way they had happened the first time. Memories that were revisited so intact and fresh add more credit to the mysterious nature of mind and time.

The Penseive that helps Harry a lot in unraveling the existing mysteries is described in the book as below:

A shallow stone basin lay there ... The silvery light was coming from the basin's contents, which were like nothing Harry had ever seen before. He could not tell whether the substance was liquid or gas. It was a bright, whitish silver, and it was moving ceaselessly; the surface of it became ruffled like water beneath wind, and then, like clouds, separated and swirled smoothly . . . Harry bent closer, his head right inside the cabinet. The silvery substance had become transparent; it looked like glass. He looked down into it . . The tip of his nose touched the strange substance into which he was staring. Dumbledore's office gave an almighty lurch - Harry was thrown forward and pitched headfirst into the substance inside the basin — But his head did not hit the stone bottom. He was falling through something icy-cold and black; it was like being sucked into a dark whirlpool — . . He was inside a memory. (Rowling, $H G F$, pp. 507-509)

Later on while still using the Penseive as a flashback provider of the events, Harry and Dumbledore made journeys to the past:

"After you," said Dumbledore, gesturing toward the bowl. Harry bent forward, took a deep breath, and plunged his face into the silvery substance. He felt his feet leave the office floor; he was falling, falling through whirling darkness and then, quite suddenly, he was blinking in dazzling sunlight. Before his eyes had adjusted, Dumbledore landed beside him. (Rowling, HHP, p.189) 
Harry stepped up to the stone basin and bowed obediently until his face sank through the surface of the memory; he felt the familiar sensation of falling through nothingness and then landed upon a dirty stone floor in almost total darkness. (Rowling, HHP, p.340)

Last but not least, we have the image of labyrinth which exists in Harry Potter and the Goblet of Fire; the last leg of the tournament for the young wizards entering a maze replete with dead ends and dangerous mysterious creatures and charms through which they had to pass and reach the center for the trophy. The winner's cup had been illegally bewitched into a Portkey so that it could Disapparate Harry to the place where Voldemort was waiting in.

\subsection{The Power of Love}

Having had claimed to be in search of a newer version of the truth and whether in Harry Potter's universe it is something of amazement as in Tlon or not, the question of the existence of an all-perceiving entity would arise. In the last confrontation with the ghost of Dumbledore, Harry becomes the young thinker of our story, trying to understand the truth:

"Tell me one last thing," said Harry. "Is this real? Or has this been happening inside my head?" Dumbledore beamed at him, and his voice sounded loud and strong in Harry's ears even though the bright mist was descending again, obscuring his figure. "Of course it is happening inside your head, Harry, but why on earth should that mean that it is not real?" (Rowling, HD, p.579)

All that was happening inside Harry's head or better to say induced by his mind were empowered and perceived into presence by an internal feeling called "Love". In an article of the Reason Papers Journal is written, "the good is love in the series which will eventually aid Harry to overcome the evil and that is the way moral imagination ought to work in society" (Prinzi, 2012, p.22), one can assume that the all-knowing ultimate god or gods of Tlon and the Supreme Spirit of Berkeley have been replaced by the power called love throughout the series. Metaphorically speaking, without love, none could have been achieved and happening in the Rowling's works. The last part, in which Dumbledore as a ghost talks of the power of love reinforces the message:

“And his [Voldemort's] knowledge remained woefully incomplete, Harry! That which Voldemort does not value, he takes no trouble to comprehend. Of house-elves and children's tales, of love, loyalty, and innocence, Voldemort knows and understands nothing. Nothing. That they all have a power beyond his own, a power beyond the reach of any magic, is a truth he has never grasped. (Rowling, $H D H$, p.568)

And in the following event when Harry chose to return to his friends and material world instead of joining Dumbledore in the world of spirits, he is advised by his deceased professor and supporter:

"Do not pity the dead, Harry. Pity the living, and, above all, those who live without love. By returning, you may ensure that fewer souls are maimed, fewer families are torn apart. If that seems to you a worthy goal, then we say good-bye for the present." (Rowling, $H D H$, p.578)

\section{Conclusion}

Based on the similar images and notions in Borges' short story “Tlon, Uqbar, Orbis, Tertius” (1941) and J.K. Rowling's seven novels of Harry Potter (1997-2007) one cannot deny the extent to which the authors have attempted in depicting worlds apart from the real one in which we are living. Herein, the power of imagination and mind in bringing into existence any object, concept or event that is materially and logically impossible is appreciated. Giving more credit and sense to this proposition, the idealism theory of philosopher George Berkeley was a helpful, however intricate tool. On the other hand, negative criticisms were made on the Harry Potter (1997-2007) novels highlighting the religious and aesthetic inappropriateness of the works compared to classic works of children's literature, and as a result, the seven novels were devalued as a mere means of monetary success construed by the author:

Is he [Cedric Diggory] truly dead? Is there an afterlife? Or does existence just end with death? These larger concerns are left unexplored, not because Rowling wants readers to contemplate such concerns; rather, she does not seem interested in serious speculation, which is a hallmark of the Tolkien, Lewis, and LeGuin fuzzy sets. (Pennington, 2002, p.92)

Stating the previous piece of criticism in the conclusion part is to add to the significance of the objective of the study, that is to convey that no matter what purpose lays behind the creation of a literary work, the fact that our minds are free to invoke different associations and allusions while reading it can still be a beacon of light. Berkeley attempted to prove the presence of an all-perceiving, supreme God through the channels of metaphysics and philosophy; likewise the forces called Mind and Love can also be claimed to respectively rule over Tlon and Harry Potter's (1997-2007) world. One should not forget that our world can be no different from either.

\section{References}

Barrenechea, A.M. (1965). Borges, the Labyrinth Maker. New York: New York University Press.

Berkeley, G. (1985). The principles of human knowledge and three dialogues between Hylas and Philonous G.J. Warnock, (Ed.). Glascow: Fantana Press. 
Borges, J.L. (1977). Merely a man of letters: an interview with Jorge Luis Borges. Philosophy and Literature, 1(3), 337-341.

Borges, J.L. (1998). Jorge Luis Borges: Collected Fictions. Trans. Hurley, A. London: Penguin Puntnam Inc.

Bossart, W.H. (2003). Borges and Philosophy. New York: Peter Lang Publishing.

Clark, J.R. (1995). Idealism and dystopia in "Tlon, Uqbar, Orbis Tertius". The International Fiction Review, 22, 74-79.

Gilson, E. \& Langan, T. (1968). Modern Philosophy: Descartes to Kant. New York: Random House.

Gupta, S. (2003). Re-Reading Harry Potter. Hampshire: Palgrave Macmillan.

Leal, L. (2005). Magical realism: theory, history, community. Parkinson, L Zamora \& Wendy B. Frais, (Ed.). U.S.A: Duke University Press.

Martin, M. (2000). Borges via the dialectics of Berkeley and Hume. Variaciones Borges, (9), 147-162.

Mellen, J. (2000). Literary topics: magic realism. Farmington Hills: The Gale Group.

Natov, R. (2001). Harry Potter and the extraordinariness of the ordinary. The lion and the unicorn, 25(2), 310-327.

Pennington, J. (2002). From Elfland to Hogwartz, or the aesthetic trouble with Harry Potter. The lion and the unicorn, 26(1), 78-97.

Reason papers. (2012). imagining better: philosophical issues in Harry Potter. C.A. Biondi, (Ed.). A Journal of Interdisciplinary Normative Studies, 34(1), 1-159.

Rowling, J.K. (1997). Harry Potter and the Philosopher's Stone. London: Bloomsburry.

_ _ . (1998). Harry Potter and the Chamber of Secrets. London: Bloomsburry.

_- - (1999). Harry Potter and the Prisoner of Azkaban. London: Bloomsburry.

- _ (2000). Harry Potter and the Goblet of Fire. London: Bloomsburry.

_ _ . (2003). Harry Potter and the Order of the Phoenix. London: Bloomsburry.

- - . (2005). Harry Potter and the Half-Blood Prince. London: Bloomsburry.

_ _ _ (2007). Harry Potter and the Deathly Hallows. London: Bloomsburry.

Winfrey, O.G. (2013, July 24). Video with J.K. Rowling Full Video. [YouTube]. Project: Interview. Retrieved from http://www.youtube.com/watch?v=Uv1O6JJMC5o 